\title{
Tatuagem: um registro de informação no corpo?
}

\author{
Tattoo: a information record on the body?
}

\author{
Samantha Thiesen Bittencourt \\ Graduada em Biblioteconomia \\ Universidade Federal do Rio Grande do Sul \\ samantha.bittencourt@acad.pucrs.br
Marcia Heloisa Tavares de Figueredo Lima
Doutora em Ciência da Informação
Universidade Federal do Rio Grande do Sul marciahelolima@gmail.com \\ Luis Fernando Herbert Massoni \\ Doutorando em Comunicação e Informação \\ Universidade Federal Rio Grande do Sul \\ luisfernandomassoni@gmail.com
}

\section{Resumo}

No contemporâneo ocidental, a modificação corporal pode servir como um meio de rememoração subjetiva ou informativa através de símbolos, adornos e demais manifestações de cunho pessoal, objetivando representar algo para si ou para o outro. As conexões entre informação e tatuagem foram abordadas a partir da visão de tatuadores sobre o corpo como um diário do indivíduo que as carrega na epiderme. Metodologicamente, o estudo é qualitativo, exploratório, de natureza básica e utiliza o método da história oral. Empiricamente, foram entrevistados três tatuadores da cidade de Porto Alegre, de modo a averiguar o ato de tatuar-se (ou a outrem) como um registro informacional. A análise das entrevistas semiestruturadas evidenciou que há diferentes razões que levam pessoas a se tatuarem e os entrevistados consideram a tatuagem como um registro de história pessoal. Algumas enunciações revelam uma intenção de informar e outras tributam o ato de tatuar-se como moda ou registro particular de memória, sem intencionalidade de informar a terceiros. Conclui-se que a tatuagem pode ser considerada ora como um registro subjetivo de memória e afeto íntimo não direcionado para outras pessoas, ora como uma oferta comunicacional de significado a outrem.

\section{Palavras-Chave}

Tatuagem. Informação. Memória e corpo. Tatuadores.

\section{Abstract}

In the contemporary Western, the corporal modification can serve as a means of subjective or informative remembrance through symbols, adornments and other personal manifestations, aiming to represent something for oneself or for the other. The connections between information and tattoo were approached from the view of tattoo artists about the body as a diary of the individual who carries them into the epidermis. Methodologically, the study has qualitative, exploratory, basic and uses the oral history method. Empirically, three tattoo artists from the city of Porto Alegre were interviewed, in order to investigate the act of tattooing to yourself (or other) as an informational record. The analysis of the semi-structured interviews showed that there are different reasons that lead people to tattoo themselves and those interviewed consider the tattoo as a personal history record. Some enunciations reveal an intention to inform and others tax the act of tattooing as a fashion or private 
memory record, without the intention of informing others. It is concluded that the tattoo may be considered sometimes as a subjective record of intimate memory and affection not directed at other people, sometimes as a communicational offer of meaning to others.

\section{Keywords}

Tattoo. Information. Memory and Body. Tattoo artists.

\section{INTRODUÇÃO}

Os fenômenos e processos informacionais são de difícil compreensão e apreensão. Definir a informação, problematizando-a, é papel da Ciência da Informação, que a constrói como objeto de estudo. $O$ presente artigo reflete sobre o caráter informacional dos registros escritos e desenhados sobre a pele humana: as tatuagens, aqui tratadas como forma de registro de informação, considerando-se a epiderme como um suporte informacional.

O uso de desenhos, linhas e demais expressões gráficas no corpo objetiva a diferenciação do indivíduo dentro dos grupos sociais em que interage ou em que se insere. Sentir-se diferente ou destacado é de grande valia na maioria dos casos, visto que o ato de tatuar-se visa quebrar normas sociais, religiosas e morais. A prática da modificação corporal, além de tornar o indivíduo destacado e diferente nos grupos, caracteriza-o como uma figura "interessante", "bizarra" ou "exótica". Pode servir como uma via de rememoração históricocultural e construção de uma identidade exclusiva, pois sua pele pode revelar informações sobre sua trajetória de vida e expor reflexões como um "livro aberto", onde a pele serviria como folhas a registrar mensagens, notas e lembretes. A principal forma de expressão artística-informativa é a escolha de símbolos, linhas e pontos para adornar o corpo. Todos os tipos de desenhos e demais "riscos" são carregados de significados e de motivações, boas ou ruins.

A pele pode ser um suporte para uma informação pessoal e, se confirmada essa hipótese, pode ser considerada uma fonte de informação para quem observa ou interage com a pessoa tatuada. Do ponto de vista da seleção, do tratamento e da disseminação de acervos, a tatuagem não é uma das formas de expressão do conhecimento privilegiadas pela Ciência da Informação. Assim, esse trabalho se justifica pela originalidade, pois a pele não é um suporte de informação tradicionalmente estudado.

A partir desta perspectiva, o estudo visou responder à seguinte questão: a pele tatuada pode se caracterizar como uma fonte de informação? O objetivo que norteou esta pesquisa foi analisar a possibilidade de tatuadores considerarem a tatuagem uma informação. Para tanto, foi tecida uma articulação teórica entre os conceitos de informação e tatuagem, perpassando o papel da memória nesse processo. Após, apresenta-se a metodologia aplicada para o desenvolvimento do trabalho, que consiste na realização de entrevistas semiestruturadas com três tatuadores experientes, orientandas pelo método da história oral. Por fim, os resultados tendem a confirmar que os tatuadores (e, possivelmente, outras pessoas tatuadas) concebem a tatuagem como uma forma de registro da informação.

\section{TATUAGEM E INFORMAÇÃO: ARTICULAÇÕES TEÓRICAS}

A informação, no seu sentido mais amplo, define-se pelo conceito de dar conhecimento, dar ciência acerca de um assunto específico ou, também, tomar conhecimento de algo ou alguém (EPSTEIN, 1986). O conteúdo informacional resolve dúvidas e faz com que apareçam mais certezas e definições sobre o mundo. Os usos e meios de suportes da infor- 
mação são os mais diversos, indo de um simples papel rascunhado até uma grande obra arquitetônica ou artística. Le Coadic $(2004$, p. 4) define que:

A informação comporta um elemento de sentido. É um significado transmitido a um ser consciente por meio de uma mensagem inscrita em um suporte espacialtemporal: impresso, sinal elétrico, onda sonora, etc. Inscrição feita graças a um sistema de signos (a linguagem), signo este que é um elemento de linguagem que associa um significante a um significado: signo alfabético, palavra, sinal de pontuação.

Para permitir que uma informação possa ser transmitida, torna-se necessário que ela esteja inserida ou registrada em um suporte. Dessa forma, conforme Oliveira (2011), como existem diversos tipos de informações, existem também variados suportes para elas. A informação tem um efeito de transformar ou reforçar o que é conhecido e, a partir das perspectivas contemporâneas da Ciência da Informação, ela não se restringe aos documentos impressos, podendo ser percebida em conversas ou qualquer outro tipo de comunicação ou prática informacional.

Em primeiro lugar é preciso esclarecer que, na ótica da Ciência da Informação, o objeto "informação" é uma representação. Como é uma representação de conhecimento, que já é uma representação do real, ela se torna uma representação da representação. Por isso, a informação é um objeto complexo, flexível, mutável, de difícil apreensão, sendo que sua importância e relevância estão ligadas ao seu uso. (OLIVEIRA, 2011, p. 18, grifo da autora).

De acordo com Cunha (2008), a informação é definida como o registro de um conhecimento, podendo ser necessária às tomadas de decisão. $O$ autor ainda expõe uma visão ampla sobre o que vem a ser a informação e como ela pode ser utilizada e expressa de diversas formas.

Com a informação podem-se realizar diversas operações, tais como: criação, transmissão, armazenamento, recuperação, recepção, cópia (em diferentes formas), processamento e destruição. A transmissão da informação é feita numa grande variedade de formas, entre as quais se incluem: luz, som, ondas de rádio, corrente elétrica, campos magnéticos e marcas sobre o papel. (CUNHA, 2008, p. 201).

Conforme González de Gómez (2000), os múltiplos significados que a informação possui atualmente remetem aos mais diversos domínios, como cognição, textos, artefatos culturais e infraestruturas. Quando tratamos sobre os tipos de suportes da informação, é necessário dissertarmos acerca da evolução da comunicação dos homens por meio da linguagem escrita, pois foi concomitante a ela que os tipos de suportes foram se modificando ao longo dos séculos.

\subsection{Uma breve história dos registros de informação}

Antes mesmo do surgimento da escrita fonética como se conhece atualmente, pinturas rupestres do período pré-histórico adornaram cavernas e grutas, eram manifestações fixadas nas rochas por meio da escrita pictográfica que lhes serviu de suportes (MARTINS, 1998). Outra forma de escrita foi utilizada pelos povos Incas e Iroqueses, que era o chamado sistema mnemônico. O sistema utilizado pelos Incas chamava-se quipos e o utilizado pelos 
Iroqueses denominava-se wampum. Essa prática consistia no uso de cordões de fios de lã compostos por diversas cores, com nós ou conchas ao longo dos fios. "O princípio do wampum é o mesmo do dos quipos; sua significação está nas cores das conchas e nas figuras formadas: por exemplo, um machado significa guerra." (MARTINS, 1998, p. 39).

Um marco na história da escrita foi quando algumas civilizações tornaram-se capazes de substituir a imagem visual pela manifestação fonética. De acordo com Martins (1998), a escrita fonética pode ser dividida entre as categorias alfabética e ideográfica. Os ideogramas começaram a representar os objetos por um sinal que os interpretasse graficamente e as ideias eram expressas por outros sinais adequados. Conforme o autor, os tipos clássicos de escrita ideográfica são o chinês, os caracteres cuneiformes e os hieróglifos. Após a fixação da utilização de uma escrita fonética alfabética, os suportes em que essa escrita foi registrada ao longo dos séculos foram criando forma e sucedendo-se por condicionantes econômicas e determinantes históricas.

Além das pedras e rochas, utilizou-se madeira e bambu como suporte da informação e, com isso, surge o papiro, às margens do Rio Nilo, no Egito. Predominantemente uma prática dos egípcios, o papiro era feito com as fibras do caule da planta umedecidas com a água turva do rio Nilo e colocadas em camadas superpostas. As folhas secavam ao sol para depois serem unidas novamente com cola de farinha (MARTINS, 1998). Ano após ano, o papiro acabou ficando escasso e a sua importação muito difícil, devido às guerras que ocorriam pela região. Dessa forma, a matéria vegetal começa a ser deixada de lado e a utilização de peles de animais se destaca, com os pergaminhos. Os mais antigos registros em pergaminho atualmente existentes datam do século III: são uma República, de Cícero, e um Virgílio, ambos integrantes do acervo da Biblioteca do Vaticano. Do século IV ao século XVI, "[...] o pergaminho foi o material mais utilizado na escrita e na França, do século IX ao século XII, apenas o pergaminho se empregava nos livros e atos." (MARTINS, 1998, p. 65).

Uma informação pode adquirir diversos significados, seguindo a forma com que um indivíduo a interpreta, possuindo diversas formas de ser expressa. A informação pode tomar a forma de um signo linguístico, iconográfico ou sonoro, podendo emanar inúmeros significados para diversos indivíduos e sempre por meio de algum suporte, seja ele o papel, o meio eletrônico ou até mesmo a pele - no caso do trabalho aqui desenvolvido, o corpo humano.

$\mathrm{Na}$ contemporaneidade, o significado da palavra "informação" perdeu o sentido de ser apenas o ato de dar forma para se tornar algo muito maior: informação passa a ser associado à "representação". O conceito de representação pode ser inserido no contexto da informação no momento em que esta traz uma reapresentação de algum tema ou assunto pertinente. Conforme Capurro (1992), a representação torna-se um meio de construir novos significados acerca dos processos humanos de significação e interpretação.

Em sua análise do sistema penal, Foucault (2014) mostra que a punição dos criminosos, até o início do século XIX, era um espetáculo público de exposição do criminoso não só pela justiça, mas por toda a sociedade atingida por ele. Uma das maneiras de criar um grande espetáculo era marcar o corpo dos condenados com o ferro em brasa, para que o mal cometido por ele ficasse para sempre em sua pele, marcado e visível no seu corpo. Além disso, Berger (2009) discorre sobre O Suplício dos Condenados (capítulo do livro de Foucault), evento esse que fazia parte da Ordenação de 1670, que regeu até a Revolução Francesa algumas formas gerais de prática penal, das quais faziam parte as penas corporais, dolorosas e mais ou menos atrozes. Nesse suplício, a intensidade e duração correspondiam ao tipo de sofrimento físico da vítima, a qualidade de danos, a gravidade do crime, a pessoa do criminoso e o nível social de suas vítimas. 
Dessa maneira, os símbolos e signos que faziam parte dos castigos impostos aos criminosos acabavam mostrando para a população que aquelas pessoas não eram confiáveis e cometeram graves erros sociais e morais.

Em relação à vítima, deve ser marcante: destina-se, ou pela cicatriz que deixa no corpo, ou pela ostentação de que se acompanha, a tornar infame aquele que é sua vítima, o suplício, mesmo se tem por função purgar o crime, não reconcilia; traça em torno, ou melhor, sobre o próprio corpo do condenado, sinais que não devem se apagar [...]. (FOUCAULT, 1987, p. 31 apud BERGER, 2009, p. 76).

Em nossa sociedade, também tivemos a presença destas marcas, tão usadas durante todo o período da escravidão e que, com certeza, reverberam em nosso imaginário. Segundo Berger (2009), é de fundamental importância constatar que estas marcas, por elas mesmas, nada dizem, ou seja: elas só podem ter um significado e serem entendidas se estiverem dentro do contexto sociocultural em que foram produzidas. Ou seja, cada marca só receberá um sentido em função do seu significado cultural, que pode mudar de local para local. As tatuagens sempre possuem uma referência direta às relações sociais, como, por exemplo, o amor à mulher, aos pais, aos animais de estimação, elogios a facções sociais, a pertença a uma tribo ${ }^{1}$, etc., que só passam a ter um sentido em sociedades específicas.

Torna-se necessário frisar bem sobre o pertencimento dado pela tatuagem, que pode ser simbólico e não obrigatoriamente efetivo: a arte pode expressar pertencimento a um grupo de motoqueiros, por exemplo, onde a maioria dos integrantes é tatuada, mas também um pertencimento virtual a um grupo em que, embora seus membros não se vejam com frequência, veem na tatuagem uma expressão de coragem, liberdade, fé e domínio sobre o próprio corpo (BERGER, 2006).

Através da articulação teórica entre os conceitos de informação e tatuagem, bem como pela análise dos processos históricos pelos quais passaram o ato de tatuar-se ou tatuar a outrem, a tatuagem pode ser considerada um registro de informação. Entretanto, compreendemos que essa relação se efetiva, sobremaneira, a partir dos aspectos mnemônicos, na medida em que a informação registrada na pele sempre tem o interesse de representar algo para ser posteriormente reconhecido e memorado.

\subsection{A tatuagem como informação e o papel da memória}

Nossas lembranças são ativadas não apenas no ato de olharmos para nós mesmos, mas também no momento em que as pessoas de fora lembram quem somos, como somos, lembram fatos cotidianos e nossas motivações a eternizar esses fatos. Podemos eternizar acontecimentos por diversos meios: cartas, livros, bilhetes, objetos de uso, roupas e também tatuagens.

As percepções do presente remontam ao conjunto de lembranças e referências do que somos ou do que um dia fomos. Segundo Halbwachs (2006), há a reflexão dos dois seres que coexistem em alguém. Um deles é sensível, uma testemunha que vem para mostrar o que viu; e um outro eu que não viu nada, mas talvez tenha visto outrora alguma informação e formado uma opinião com base no testemunho do mundo ao seu redor. Conforme o autor, quando nos encontramos, nos deparamos com o passado, evocamos todas as informa-

\footnotetext{
${ }^{1}$ Aqui utilizamos "tribo" em amplo sentido: as tribos de sociedades de memória (sem escrita) e as tribos urbanas contemporâneas.
} 
ções possíveis para entender a presença daquele passado no presente, bem como o motivo que ele retorna e permanece junto de nós.

A partir das reflexões acerca da leitura de Halbwachs (2006), compreendemos que a tatuagem é o presente que remonta a um passado e, por consequência, um passado que nos acompanha no presente e nos acompanhará no futuro - a não ser que a morte ou o laser separe essa ligação, esse laço passado-presente que o tatuado cria no momento em que começa o primeiro traço de sua tatuagem. É uma rememoração do que foi, do que é e do que vai ser durante a vida. As marcas na pele podem sofrer mudanças, podem ser cobertas por novos significados, apagadas por completo ou serem completadas por novas informações que surgiram no emaranhado da mente humana.

Com a marca corporal, por mais que quiséssemos desistir ou apagar totalmente uma memória, ela permanece no corpo: no braço, na mão, no peito, na perna, na costela... ela está presente, por mais que a roupa tape, por mais que não se fale sobre a existência dela, a história de vida está escrita nesse suporte diferenciado e pouco comum: a pele.

Os sentimentos experimentados de carregar recordações, rostos, escritos e histórias de uma vida são pertencentes apenas ao tatuado, visto que a pele dele é como um livro aberto, um livro onde as páginas não podem ser arrancadas, por mais que, às vezes, se tenha vontade. O tatuado é um livro aberto, exposto para os outros, sendo que essa "informação de si" que o sujeito produz ao se tatuar serve não só para si, mas para se identificar e informar aos outros.

Entretanto, cabe ponderar que, embora a informação esteja ali registrada e visível ao outro em forma de tatuagem, apenas o sujeito tatuado é que sabe efetivamente o que ela significa. Ou seja: o corpo se assemelha a um livro aberto, mas codificado. Isso significa que muitos símbolos, escritos e desenhos podem ter diversos significados, de acordo com quem os tenta ler.

Todos os desenhos, linhas e escritos que uma pele possui rememoram a fatos que, muitas vezes, não foram registrados em um vídeo, uma foto ou um memorando. A pele é um suporte informacional ambulante, com duração de, no máximo, uma vida, mas que pode explicar diversas experiências que a pessoa passou ao longo da vida.

A tatuagem é considerada por Costa (2014) como um signo, uma "mácula" que a pessoa doravante tatuada opta por registrar na epiderme, seu suporte móvel e perene. 0 signo é o indício da presença física e imediata de alguma coisa ou algum evento a ser representado. $\mathrm{O}$ ato de marcar a pele é um ato de comunicação não-oral, onde o desenho, risco, cor ou até palavras podem significar uma ideia ou toda uma personalidade, inclusive. O objetivo do signo é ter um significado duradouro, transcendente, que cause reações emocionais e se concretize no presente, seguindo sempre com a pessoa que o porta (RODRIGUES, 2006).

A partir das reflexões de Assmann $(2011)^{2}$, podemos compreender que as escritas do corpo surgem como algo muito além dos exemplos de escritas conhecidos, como pedras entalhadas e papéis rascunhados: nem os danos da vida podem apagar um registro na pele. Metaforicamente, é como uma marca que pode chegar até a alma. O cérebro e o coração deixam de serem os órgãos de memória por excelência, passando a dividir recordações com a pele.

Ainda a respeito das inscrições no corpo, lembramos das iniciações de homens e muIheres em tribos: experiências nas quais dor e memória caminham juntas. Conforme Assmann (2011), o etnólogo Pierre Clastres identificou, em seus estudos, que essa relação im-

\footnotetext{
${ }^{2}$ A perspectiva da autora foge um pouco à abordagem deste estudo, pois aborda as marcas corporais a partir de experiências traumáticas, tais como o Holocausto.
} 
pede que haja um esquecimento de informações de fatos relevantes, da história daquela pessoa. A memória corporal de feridas e cicatrizes é mais confiável do que a memória mental, pois a idade avança, mas a pele não nos deixa esquecer ou mentir. Segundo a autora, as escritas corporais foram tematizadas por meio de contextos bem diferentes e interpretadas ou avaliadas de diferentes formas, de acordo com a metafísica que lhes servia de orientação.

Com relação à tatuagem como registro de memória, podemos também argumentar sobre o conceito do corpo como um "livro vivo", pois nesse momento o corpo do indivíduo tatuado é utilizado como um suporte para expressar algo. Como afirma Araújo (2010, p. 65), "[...] parece teimosia. Mas é o corpo que não para de emitir mensagens, como um velho sobrevivente feito de carne, na grande máquina de produzir imagens e espetáculos.".

Por muitos anos, o papel, ligado somente à expressão da palavra escrita, passou a dividir espaço com outros suportes, considerados como "documentos": instrumentos, objetos, prédios, vestuários, alimentos... tudo o que possa ser portador de significados. Conforme Tammaro e Salarelli (2008), o documento não é mais somente algo legível na forma escrita: o documento é fruto da capacidade do pesquisador para interrogar um material. Dessa forma, a tatuagem caracteriza-se como um novo modo de informação, tendo na pele o seu suporte.

Assim como as pessoas identificam-se com a capa e com o conteúdo de um livro, elas também podem identificar-se com a tatuagem de outras pessoas tatuadas. Para boa parte dos tatuados, aquilo que é gravado na pele é o seu sentimento mais verdadeiro, é a prova do que aconteceu em tempos passados e que se deseja perpetuar pela vida toda, estando presente todos os dias naquelas cores ou apenas em cor de tinta preta; é a ideia de se tornar um livro vivo, um documento ambulante carregado de memórias e vontades.

\section{ASPECTOS CONTEXTUAIS E METODOLÓGICOS}

Nesta seção, são descritos o tipo de estudo realizado, os processos de pesquisa, os procedimentos para a coleta de dados e, ao final, como eles foram analisados para dar conta do objetivo proposto. A pesquisa teve natureza básica, sob um viés exploratório, considerando-se que a discussão da tatuagem como informação é incipiente. Trata-se de uma pesquisa qualitativa que foca no caráter subjetivo do objeto analisado, estudando particularidades e experiências individuais. Esse trabalho caracteriza-se como um estudo com viés fenomenológico, entendendo-o como um discurso intuitivo e não só descritivo.

$\mathrm{Na}$ oportunidade do estudo, imaginou-se ouvir pessoas com experiência em tatuagem e, nesse sentido, realizou-se um estudo exploratório em que se deu voz a alguns tatuadores - sujeitos que, em geral, também são pessoas tatuadas. Assim, considerou-se útil a recolha de narrativas de pessoas tatuadas que exemplificassem o conteúdo informacional contido em suas respectivas tatuagens ou de pessoas que eles já tatuaram. Nesse sentido, o método da história oral orientou este estudo, permitindo "[...] a interpretação da história e das mutáveis sociedades e culturas através da escuta das pessoas e do registro de suas lembranças e experiências." (THOMPSON, 2002, p. 9). Assim, nosso intuito foi compreender o fenômeno em estudo por meio da escuta das vozes dos sujeitos com experiência no assunto.

Esse método pareceu adequado na medida em que não objetivamos capturar um estudo exaustivo acerca de todos os dados relevantes sobre o tema estudado, mas sim um segmento da experiência humana (HAGUETTE, 1992). Além disso, convém lembrar que a história oral, tradicionalmente, se preocupou em explorar temas antigos ou marginais, quando não "inúteis" (SANTAMARINA; MARINAS, 1993), ou seja, temas pouco explorados ou 
reconhecidos pela ciência tradicional. Nesse sentido, tendo em vista o preconceito que circunda a temática da tatuagem, esse método se mostrou apropriado.

\begin{abstract}
A história oral é, inevitavelmente, uma zona de fronteira, não tanto entre disciplinas, mas entre a própria academia e o mundo real, entre a memória legítima, cientificamente produzida [...] e as memórias individuais, no que tem de pessoal e de coletivo. Se há, como muitos defendem, um confronto entre essas memórias, a história oral se localiza em pleno front. (GUARINELLO, 1998, p. 63).
\end{abstract}

Os sujeitos da pesquisa foram três tatuadores experientes da cidade de Porto Alegre que se dispuseram a contar a história de suas tatuagens, sua percepção sobre o ato de tatuar-se, bem como intentaram rememorar histórias de pessoas tatuadas que indicassem reflexões sobre o conteúdo das imagens tatuadas. Para este fim, foram aplicadas entrevistas semiestruturadas contendo as seguintes perguntas:

a) Com que idade você começou a se tatuar?

b) Tem ideia de quantas tatuagens você carrega hoje?

c) Qual você diria que é sua relação com a tatuagem?

d) Quais motivos te levaram a ser tatuador?

e) Você pode contar pra gente o que você tem tatuado no corpo? Alguma história sobre um desenho em específico?

f) Cada tatuagem tem uma história. Você gostaria que as pessoas identificassem o que você quer contar com os desenhos?

g) Quando você se tatua, evidentemente você está registrando algo para si mesmo. Mas você considera que também está representando algo para os outros, para quem te vê? Ou sua intenção é que cada um imagine e assim crie suas próprias viagens? Te chateia os múltiplos significados das "leituras" das tuas tatuagens? Você gosta que as pessoas perguntem os significados de cada tatuagem?

h) Seus clientes costumam comentar a história de cada tatuagem? Poderia destacar algumas histórias de tatuagens contadas por clientes?

A princípio, estas interações se deram no formato semiestruturado, com perguntas acerca das motivações para os temas e desenhos das tatuagens, de acordo com as narrativas e tipos de tatuagens de cada entrevistado. Algumas dessas perguntas foram norteadas pelo resultado do referencial teórico acerca dos conceitos de informação, tatuagem e memória. Todos os entrevistados assinaram um Termo de Consentimento Livre e Esclarecido, permitindo o uso desses dados na pesquisa, bem como sua publicação.

Uma questão que surgiu durante o processo de pesquisa foi acerca da suficiência dos dados para análise. Nesse sentido, a opção de realizar somente três entrevistas pareceu suficiente, já que este trabalho é uma pesquisa exploratória sobre as possibilidades de conectar a tatuagem com a noção de informação. A análise dos dados confirmou algumas das articulações teóricas construídas no referencial que embasa este estudo, como é possível perceber a seguir.

\title{
4 A VISÃO DOS TATUADORES SOBRE A TATUAGEM COMO INFORMAÇÃO
}

Foram realizadas três entrevistas com tatuadores da cidade de Porto Alegre. Todos possuem várias tatuagens, indicando que enfatizam a tatuagem como adorno ou enuncia- 
ção. Analisando os resultados das entrevistas, foram selecionados alguns trechos para confrontar com os aspectos teóricos destacados na seção dois deste artigo. Nas entrevistas realizadas, constataram-se menções aos conceitos de "registro" e de "história [de vida] pessoal". Os indivíduos entrevistados demonstram apreço pela tatuagem (como arte e como forma de expressão), bem como se dispuseram a narrar o histórico de alguns desenhos.

Percebeu-se que os tatuadores não estabelecem elos ou conexões entre tatuagem e informação, pois não percebem que o registro corporal carrega sentidos latentes, podendo contar uma história e estabelecer elos comunicativos. Constatou-se que a marca corporal, os escritos, as cores e desenhos, podem ser considerados como uma maneira de representação e de significação subjetivas para os indivíduos entrevistados. Segundo suas visões, o sujeito tatuado se individualiza e se destaca, ganha um papel diferente aos olhos do público, pois se difere por carregar um conteúdo pessoal, mnemônico, mas não percebido como "informacional". Considera-se que informação, em nosso domínio, carrega uma "potência" de comunicação ou ligação e existiria uma relação informacional em função de uma produção de sentido pelo sujeito receptor, além de uma carga de intencionalidade do sujeito emissor.

Reunindo os dados coletados durante as entrevistas, constata-se que a média de idade em que os entrevistados começaram a se tatuar foi de 17 anos. Já em relação ao número de desenhos, os três entrevistados já perderam as contas de quantas tatuagens possuem. Há de se lembrar de uma característica da "tribo" dos tatuados: dificilmente se fica com um desenho só e tampouco cada tatuagem é o último desenho a ser feito; enquanto houver pele, dinheiro e resistência à dor, o corpo é enfeitado, igual um templo ou uma casa, onde o indivíduo sente-se bem - é a noção de pele como roupa permanente.

Os entrevistados foram questionados acerca de qual a sua relação com a tatuagem. O entrevistado 3 alega:

É mais paixão pra vida do que... do que qualquer outra coisa. Até tenho que levar como profissão, sim... senão eu não tenho como pagar as contas... [risos]. Mas eu levo mais como um estilo de vida do que qualquer outra coisa, né? É como se fizesse parte de mim já.

Identificamos, nas respostas a essa pergunta, que, para eles, a tatuagem é mais do que uma forma de sustento, pois eles demonstram um forte vínculo afetivo com o ato de tatuar-se ou tatuar ao outro. Eles compreendem a tatuagem como algo que perpassa toda a sua vida, marcando a sua construção identitária e, possivelmente, a dos outros.

Além disso, o entrevistado 1 afirma que, há muitos anos, ele não usava bermudas e camisas de manga curta devido à vergonha por ser magro, tabu que começou a quebrar quando tatuou os braços e as pernas, pois, a partir do evento de tatuar-se, ou "vestir-se com tatuagens", ele começou a sentir-se bem em mostrar essas partes do corpo. Nas palavras dele: "[...] a tatuagem é uma forma de expressão. [...] então fui me expressando um pouco mais e hoje, se eu precisar andar de cueca na rua, vou andar... [risos]." Fica evidente que a tatuagem é compreendida por ele como uma maneira de apresentar-se para o mundo, tanto que, quanto mais tatuagens ele tem, mais desinibido fica em expor seu corpo. $O$ ato de tatuar-se, nesse sentido, parece estar relacionado à vontade de vestir uma segunda pele, pois, para esse sujeito, os outros são aqueles que o observam. Isso significa que a tatuagem pode ser considerada como uma tentativa de construção de uma representação a seu respeito, pois ele afirma sentir-se à vontade para exibir seu corpo por causa da presença das tatuagens. 
Sobre as motivações que os levaram a tornarem-se tatuadores, os entrevistados 2 e 3 referiram-se ao amor à arte, ao desenho e também pela vontade de poder trabalhar no ofício e no meio em que não haveria preconceito, o que permitiria sua inclusão como cliente e como profissional. Outro questionamento foi sobre o que cada um tem registrado em seu corpo. $O$ entrevistado 1 relatou sobre a imagem de sua esposa tatuada no braço direito feita pela técnica de realismo colorido. Também leva consigo o nome da filha com a técnica de lettering ${ }^{3}$ na barriga, considerando o nascimento dela a coisa mais importante que aconteceu na vida dele, pretendendo ainda tatuar o rosto da criança, assim como tem o retrato da esposa.

Esse tatuador ainda tem algumas tatuagens curiosas, que fez questão em comentar: uma delas, dedicada às pessoas que ficam olhando para ele no ônibus, é uma frase na canela escrita: "Rafa quer que vocês se fodam" (Figura 1), seguida de outra frase, na outra canela: "Estranho é você sem tatuagem". Dessa maneira, ele quer reafirmar que ama tatuar-se, mas também carrega símbolos de protesto e de rejeição a quem tem preconceitos.

Figura 1 - Tatuagem do Entrevistado 1

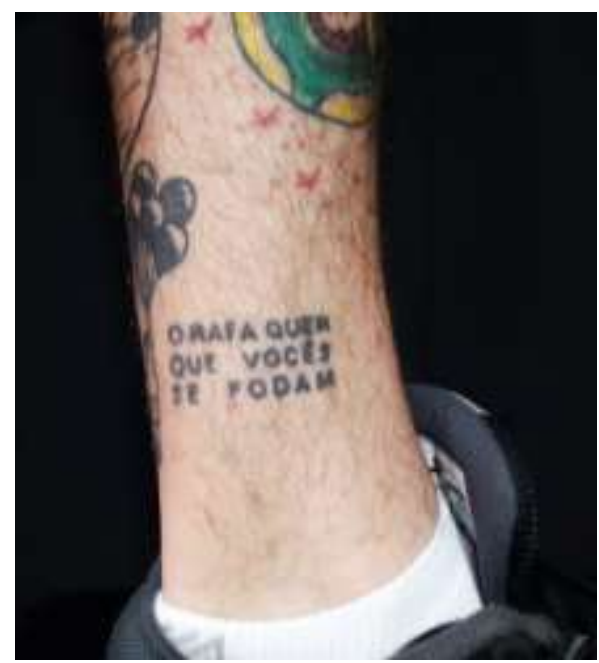

Fonte: Autores (2017).

Este entrevistado carrega esta tatuagem em que ostensivamente sugere que não lhe interessam as interpretações acerca de suas tatuagens por parte dos outros: esta tatuagem indica que não há intento de dialogismo. No entanto, a segunda tatuagem dá sequência a um diálogo imaginado com receptores intrusos. Esse uso da tatuagem como uma forma de contestação, por parte do entrevistado, remete à reflexão sobre os usos sociais e políticos das ações de informação, bem explorados por González de Gómez (1999), nos quais a informação é utilizada nos embates ideológicos, sempre situada em regimes próprios, que marcam seu contexto. Em outras palavras, em um contexto social em que ainda se percebe o preconceito contra tatuados, a inscrição desse sujeito seria um jeito de informar aos outros dos seus valores e da sua opinião.

O entrevistado 2 possui a palavra "conquista" tatuada no braço, fazendo o seguinte relato:

\footnotetext{
${ }^{3}$ É um estilo de tatuagem que consiste na arte de desenhar e criar letras. A combinação dessas letras serve para um objetivo, uma utilização específica e uma finalidade. É como uma ilustração, mas a ilustração são as letras.
} 
[...] desde pequeno eu nunca ganhei nada, assim... na verdade, né. Claro, não condeno meus pais, nada assim, mas... nunca foi de mão beijada, assim... sempre foi batalhado, né? Sempre foi conquistado. Inclusive na relação com meus pais, sabe, desde o início a gente sempre passou trabalho, meus pais moram de aluguel até hoje... tudo, entendeu? Então sempre foi difícil, eu sempre acompanhei isso, sempre foi um jogo aberto entre nós... a mãe nunca escondeu 'ah, tá tudo bem'... não. Ela sempre... 'ah, tamo passando trabalho, vai ter que... é... pra pagar o aluguel esse mês, vai ter que se livrar de tal coisa...'. Sempre foi uma conquista. Então hoje acredito que onde eu tô assim, foi tudo por conquista.

Enquanto o entrevistado 2 tem como principal memória corporal, uma palavra de significado forte, da superação de barreiras, o entrevistado 3 tem dois registros interessantes e distintos: o nome da avó, o qual foi de grande valia em sua vida; e o outro desenho, um chapéu de palha, do personagem Luffy, do desenho animado japonês OnePiece, que é a animação preferida dele. Neste caso, percebe-se que o objetivo da tatuagem é manter uma memória viva, seja ela uma pessoa, um objeto ou um produto da indústria cultural com o qual se identifica (como é o caso da animação referida pelo entrevistado).

Esses usos da tatuagem como forma de lembrar alguém ou de lembrar, através de uma palavra tatuada, momentos passados na companhia de familiares, remetem ao fundamento da memória coletiva apontado por Halbwachs (2006) de que nunca estamos só. Por fazermos parte de grupos sociais, é como se nunca estivéssemos sós, pois nos lembramos dos outros (a família, no caso) e esse sentimento de pertencimento com o grupo orienta nossas práticas sociais. Assim, ao olhar suas tatuagens, essas pessoas relembram seus familiares e isso orienta suas vidas e as constitui enquanto sujeitos. Em outras palavras, a tatuagem seria um meio de memória ao lembrar, ao tatuado, que ele nunca está só.

Figura 2 - Caixa de Madeira com Estênceis Usados

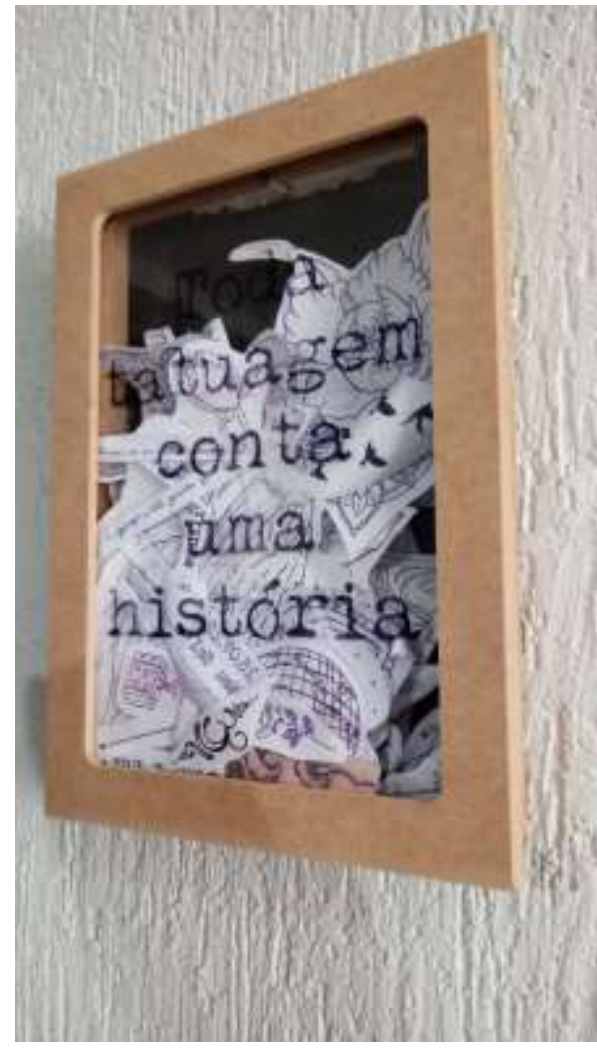

Fonte: Autores (2017). 
Acerca do debate da tatuagem ser informativa ou não, se ela conta uma história, o entrevistado 1 defende a ideia de que a tatuagem é, sim, uma informação, e que conta a história de vida de um indivíduo. Ao mesmo tempo, ele revela uma caixa de madeira (Figura 2) em que guarda os estênceis" utilizados nos clientes, com o escrito "Toda tatuagem conta uma história". Ele relata que não está interessado em informar as pessoas com seus desenhos, mas ressalta a importância das tatuagens com fins médicos, como as tatuagens que informam sobre alergias a medicamentos, doenças crônicas e também tipo sanguíneo, em casos de acidentes.

Os múltiplos significados que um desenho pode ter, como exposto durante a pesquisa, são comentados pelos três entrevistados, mas o entrevistado 1 é o que mais se destaca e demonstra conhecimento sobre o quanto isso pode determinar um julgamento ou também uma maneira de tratar o indivíduo em meio a pessoas não tatuadas.

Quando perguntados sobre a importância que dão para o que as pessoas pensam ou também para o que significam para os outros, os entrevistados demonstram diferentes comportamentos. $O$ entrevistado 1 mostra que entende os múltiplos significados que uma tatuagem pode ter, procurando entender e respeitar o que analisam dos seus desenhos, mas, apesar de dizer que não "esquenta a cabeça" com os julgamentos e comentários sobre as tatuagens, ele tem uma tatuagem bem significativa de uma resposta, na contramão do que ele considera um olhar agressivo.

Os entrevistados 2 e 3, como não possuem uma tatuagem em resposta aos olhares estranhos das pessoas na rua ou em locais fechados, relatam que não ligam para o que pensam sobre seus desenhos, mas não se sentem confortáveis com olhares e preferem (assim como o entrevistado 1) que as pessoas perguntem sobre algum desenho que lhes chamem atenção, em vez do olhar direto, rude, invasivo e sem explicação. Os três indivíduos incomodam-se quando são observados sem interrupções e, muitas vezes, se contêm para não falar coisas agressivas ou repreensivas por se sentirem analisados de maneira duvidosa.

Um ponto interessante (porque inesperado) durante a pesquisa é sobre o entrevistado 1: ele mantém um "arquivo" ${ }^{5}$ das tatuagens que significaram para ele, com o uso da caixa de madeira com os carimbos (os já referidos estênceis) das tatuagens de clientes, bem como postagens na rede social virtual Instagram, contando a história dos trabalhos feitos e também dos clientes que passaram por ele. $O$ interessante desse conjunto desorganizado de registros é ele ter uma memória, um material de pesquisa, dos desenhos e histórias que já passaram pela carreira dele. É um souvenir do trabalho de tatuador, pois, após a aplicação do estêncil, da realização da tatuagem e da imagem registrada com máquina fotográfica ou celular, pouco se tem de lembrança, de memória do cliente, pois fotos podem perder-se com o tempo. Mas, se o estêncil não for colocado no lixo (procedimento padrão após a escoIha do local do desenho e aplicação na pele), ele é feito com papel carbono, possuindo duração longa e servindo de memorial.

Por fim, quando questionados sobre histórias de clientes, todos os três entrevistados relataram memórias afetivas em desenhos solicitados pelos clientes, reforçando que a tatuagem possui caráter de informação, mesmo que seja individual e sem a intenção de inter-

\footnotetext{
${ }^{4} \mathrm{O}$ papel hectográfico é utilizado para transferir o desenho para a pele, sendo indispensável o uso de creme, bastão ou spray para fixar o desenho na pele (os contornos do desenho em cor roxa). É o processo inicial para o começo da tatuagem, pois é com a aplicação do estêncil que o cliente define se o local que ficará o desenho é bonito ou não.

5 "Arquivo" entre aspas porque não corresponde a um arquivo organizado, mas a "arquivo" no sentido de guarda e preservação dos desenhos feitos, ainda que de forma pessoal e assistemática.
} 
pretação externa. Como exemplos, temos uma homenagem de uma mãe que perdeu seu filho prematuramente, mas que gostaria de manter viva a memória dele em sua pele, tatuando um desenho que remetesse ao tempo em que ele esteve com ela na gestação. Outro caso é sobre um rapaz que fez uma promessa para uma entidade de religião de matriz africana, para que o pai não utilizasse mais álcool, tendo sido atendido e o período de calmaria e agradecimentos já duram 10 anos.

Cada entrevistado reage de uma maneira com questionamentos sobre o mundo da tatuagem, mostrando sua personalidade e seu conhecimento sobre esse assunto. $\mathrm{O}$ corpo consiste em uma construção social, sendo aprimorado e adaptado de acordo com os padrões que cada sociedade exige para que o indivíduo portador desse corpo possa viver "bem" nela. De acordo com o meio social em que está inserido, existem tribos nas quais o indivíduo poderá ser obrigado a tatuar-se na sua passagem da infância para a adolescência, representando uma marca dessa transação. Noutros casos, a tatuagem é apenas um adorno corporal, quebrando regras e também se diferenciando dos padrões "normais" de sociedade.

Em suma, após os três encontros e conversas com os tatuadores, sabemos que, quando uma tatuagem é realizada, a mensagem que o ato de tatuar-se pode passar nem sempre será compreendida por todos e, para que possa transformar-se em informação, o receptor precisa atribuir-lhe algum significado.

\section{CONCLUSÕES}

A imagem pictórica antecedeu muito a comunicação escrita como forma de comunicação social. Representar algo faz parte de um processo de significação e, para que um signo faça a representação de alguma coisa, é necessário que ele estimule algo já presente na consciência do indivíduo receptor, é necessário que existam "condições de possibilidade". Dessa maneira, a fim de que a imagem passe uma ideia, para que possa sair do campo mental de uma pessoa e integrar o campo visual de outra, é necessário que a informação seja representada. Entretanto, nem toda imagem que é representada de forma visual é capaz de ser compreendida por todos - e isso ocorre com as tatuagens. O portador de uma tatuagem, muitas vezes, nem quer que a imagem tatuada comunique algo a outrem, como os resultados da pesquisa evidenciam.

As tatuagens são representações gravadas na pele em forma de imagens, símbolos ou signos linguísticos. Elas contêm e transmitem uma informação, por vezes transcendendo o sujeito tatuado - emissor que não decide o significado atribuído à tatuagem a cada releitura dela. $\mathrm{O}$ ato de tatuar-se é construído culturalmente, assim como o significado atribuído a cada tatuagem, que é uma possibilidade de recepção, apreensão e interpretação. Pode-se afirmar que a tatuagem é mais do que um modo para passar uma mensagem, ela pode ser uma significação pessoal mais ligada à ideia de memória individual. Mas, ao mesmo tempo, pode funcionar como uma disponibilidade, uma oferta de significação que carrega uma indecidibilidade estrutural. Neste segundo caso, atua de modo informacional.

Os indivíduos tatuados atribuem aos seus desenhos na pele um significado, e mais: cada imagem registrada na pele possui um significado nas relações reais, mas também pode ser capaz de possuir muitos outros significados virtuais, incontroláveis pelo indivíduo tatuado. Uma tatuagem de uma flor representa, inicialmente, o vegetal flor, mas, para o indivíduo que possui tal desenho, pode significar o seu amor pela natureza, pela flor como ornamento, pode significar uma oferta de simpatia e doçura frente a um mundo hostil, etc. Qualquer 
outra pessoa que veja tal flor, pode atribuir um significado distinto: doçura, celebração da natureza e muitos outros.

Este estudo teve um caráter exploratório, o que se percebe nas dificuldades teóricas para relacionar conceitos de mundos, a priori, tão distintos. Como pista para futuros estudos, há a possibilidade de aprofundamento da proposta, talvez pelo caminho da análise da importância dos atos de fala e de expressão da linguagem. Considerando os resultados e as análises bibliográficas, reconhecemos as lacunas e as possibilidades do trabalho como horizonte de pesquisa. Por exemplo, poderíamos ter ampliado o número de entrevistados, o que, certamente, abriria muitas outras falas e possibilidades de conexão com o fenômeno informacional. Abre-se uma porta para explorar o problema de investigação, se possível, sempre conectando saberes interdisciplinares necessários à compreensão dos meandros do mundo da tatuagem.

\section{REFERÊNCIAS}

ARAUJO, Leusa. Tatuagem, piercing e outras mensagens do corpo. São Paulo: Cosac Naify, 2010.

ASSMANN, Aleida. Espaços da recordação: formas e transformações da memória cultural. Campinas: Editora da Unicamp, 2011.

BERGER, Mirela. Corpo e identidade feminina. 2006. $312 \mathrm{f}$. Tese (Doutorado em Antropologia) - Faculdade de Filosofia, Letras e Ciências Humanas, Universidade de São Paulo. São Paulo, 2006.

BERGER, Mirela. Tatuagem: a memória na pele. Sinais, Vitória, n. 5, p. 65-83, set. 2009.

CAPURRO, Rafael. Epistemology of Information Science. In: Relatório... Ed. Stephan Schwarz, 1985. Disponível em: www.capurro.de/trita.htm. Acesso em: 27 fev. 2018.

COSTA, Ana. Tatuagem e marcas corporais: atualizações do sagrado. São Paulo: Casa do Psicólogo, 2014.

CUNHA, Murilo Bastos da. Dicionário de Biblioteconomia e Arquivologia. Brasília, DF: Brinquet de Lemos, 2008.

EPSTEIN, Isaac. Teoria da informação. São Paulo: Editora Ática, 1986.

FOUCAULT, Michel. Vigiar e punir: nascimento da prisão. Petrópolis: Vozes, 2014.

GONZÁLEZ DE GÓMEZ, Maria Nélida (Org.). Interdiscursos da Ciência da Informação: arte, museu e imagem. Rio de Janeiro: IBICT, 2000.

GONZÁLEZ DE GÓMEZ, Maria Nélida. O caráter seletivo das ações de informação. Informare, Rio de Janeiro, v. 5, n. 2, p. 7-31, 1999. 
GUARINELLO, Norberto Luiz. Breve arqueologia da história oral. História Oral, v. 1, p. 61-65, 1998.

HAGUETTE, Teresa Maria Frota. A entrevista. In: HAGUETTE, Teresa Maria Frota. Metodologias qualitativas na Sociologia. 14. ed. Petrópolis: Vozes, 1987. p. 81-86.

HALBWACHS, Maurice. A memória coletiva. 2. ed. São Paulo: Centauro, 2006.

LE COADIC, Yves-François. A ciência da informação. 2. ed. Brasília, DF: Briquet de Lemos, 2004.

MARTINS, Wilson. A palavra escrita: história do livro, da imprensa e da biblioteca. 3. ed. São Paulo: Ática, 1998.

OLIVEIRA, Marlene de (Org.). Ciência da Informação e Biblioteconomia: novos conteúdos e espaços de atuação. 2. ed. Belo Horizonte: Ed. UFMG, 2011.

RODRIGUES, Apoenan. Tatuagens: Dor. Prazer. Moda. E muita vaidade. São Paulo: Editora Terceiro Nome, 2006.

SANTAMARINA, Cristina; MARINAS, José Miguel. Historias de vida e historia oral. In: SANTAMARINA, Cristina; MARINAS, José Miguel (Org.). La historia oral: métodos y experiências. Madrid: Debate, 1993. p. 257-285.

TAMMARO, Anna Mari; SALARELLI, Alberto. A biblioteca digital. Brasília, DF: Briquet de Lemos, 2008.

THOMPSON, Paul. História oral e contemporaneidade. História Oral, n. 5, p. 9-28, 2002. 